\title{
SPOKOJENOST ŠKOLNÍCH PSYCHOLOGŮ A POHLED NA KLADY A ZÁPORY JEJICH PRÁCE
}

\author{
Marie Herynková
}

\begin{abstract}
Abstrakt
Výzkumná studie se zabývá pohledem školních psychologů na klady a zápory jejich profese. Dále je výzkum zaměřen na zjištění úrovně spokojenosti školních psychologů se svou prací. Z výsledků vyplývá, že mezi nejčastěji zmiňované kladné aspekty práce školních psychologů patří možnost přímé práce s klientem, volnost časová i ve způsobu pojetí práce a rozmanitost. Naopak nejčastěji zmiňovanými zápory byly náročné vztahy na pracovišti, nejasná role a osamocenost. Velká část výzkumného souboru $(\mathrm{N}=61$, z toho 59 žen) je pracovně spokojena. Byla nalezena statisticky významná souvislost mezi touto spokojeností a délkou praxe i výší úvazku školních psychologů.
\end{abstract}

Klíčová slova: školní psycholog, školní psychologie, pracovní spokojenost

\section{JOB SATISFACTION OF SCHOOL PSYCHOLOGISTS AND THEIR VIEW ON THE POSITIVE AND NEGATIVE ASPECTS OF THEIR WORK}

\begin{abstract}
The research study discusses the view of school psychologists on the positive and negative aspects of their profession. In addition, the research aims to discover to what extent school psychologists are satisfied with their work. The results show that the most frequently mentioned positive aspects of the work of school psychologists are the possibility of direct work with clients, a flexible work schedule and a flexibility in working approach and diversity. On the contrary, the most frequently mentioned disadvantages are difficult relationships in the workplace, unclear role, and loneliness. A large part of the respondent sample $(N=61,59$ women) are job-satisfied. A statistically significant correlation was found between job satisfaction and the practice length as well as the number of weekly working hours.
\end{abstract}

Keywords: school psychologist, school psychology, job satisfaction

Došlo: 5. 12. 2019

Schváleno: 7. 9. 2020 


\section{Úvod}

Ačkoliv je u nás dlouhá tradice školních psychologů, tak až v posledním desetiletí došlo k významnému nárůstu pracovních pozic psychologů na českých školách. K nárůstu počtu školních psychologů nedošlo jen díky zájmu škol, ale také díky projektům Evropské unie, které dlouhodobě podporovaly prŕitomnost školních specialistů na školách (Smékalová, 2014). K zvýšení počtu školních psychologů pomohlo i inkluzivní vzdělávání v souvislosti s novelou školského zákona č. 82/2015, která vešla v platnost od září 2016. Ministerstvo školství, mládeže a tělovýchovy na podporu inkluzivního vzdělávání zavedlo projekt s názvem Šablony. Šablony mají za cíl pomoci školám získat, co potřebují, bez složité projektové dokumentace. Umožňují školám získat školního psychologa na poloviční nebo celý úvazek (Borečková, 2018). O práci školního psychologa projevilo zájem $42 \%$ studentů psychologie ve výzkumu realizovaného na Slovensku v roce 2013 (Vašašová \& Tóth, 2015).

Profese školního psychologa nebyla dlouho legislativně zakotvena a rovněž chyběly metodické materiály, což znesnadňovalo fungování školních psychologů (Braun a kol., 2014). $\mathrm{Z}$ důvodu chybějící legislativy pracovali školní psychologové pod různým pracovním zařazením, např́íklad jako vychovatelé nebo učitelé (Zapletalová, 2001). Situace se zlepšila $\mathrm{v}$ roce 2005, kdy došlo k právnímu zakotvení školních psychologů vyhláškou č. 72/2005 Sb. o poskytování poradenských služeb ve školách a školských zařízeních, která byla doplněna i metodickým materiálem. Ve vyhlášce č. 72/2005 Sb., v př́loze č. 4, jsou uvedeny standardní činnosti školních psychologů. Náplň práce školního psychologa je vymezena i ve vyhlášce č. 116/2011 Sb., ve znění pozdějších předpisů, přičemž se jedná o diagnostiku a depistáž, konzultační, poradenskou a intervenční práci, metodickou a vzdělávací činnost. Štech a Zapletalová (2013) upozorňují na riziko nižší kvality psychologických služeb z důvodu nízkého pracovního úvazku školních psychologů.

Ukazuje se, že školní psychologové jsou prrínosem pro školní poradenská pracoviště (Bartoňová a kol., 2019), i když spokojenost školy s jejich prací se odvíjí hlavně od osobnosti a odborných kompetencí každého z nich (Knotová a kol., 2014).

\section{Výhody a úskalí profese}

Výhody a úskalí profese u českých školních psychologů jsou popsány v odborných článcích (Smékalová, 2014; Vozková \& Vanek, 2018; Zapletalová, 2001) a monografí́ch (Braun a kol., 2014; Štech \& Zapletalová, 2013), jejichž výčet stručně nastíníme v této podkapitole.

Pro většinu škol byla doposud přítomnost školního psychologa něco nového, což s sebou neslo nejasnosti ohledně náplně práce a různá očekávání zúčastněných aktérů (žáků, rodičů, učitelů, vedení). Gajdošová a Valihorová (2019) popisují nové profesní role školních psychologů vyplývající ze současné školní praxe na Slovensku: manažer/lídr, aktér/ podporovatel duševního zdraví, spolupracovník při realizaci inkluzivního vzdělávání, poradce/ konzultant/ kariérní poradce, facilitátor/ mediátor, diagnostik, realizátor prevence a intervence. Role aktéra/ podporovatele duševního zdraví souvisí s rozvojem pozitivní psychologie a aplikací poznatků do školství, přičemž zejména v zahraniční literatuře najdeme výzkumy zaměřené na podporu duševního zdraví žáků a jejich pozitivní rozvoj. Gajdošová (2017) uvádí jako novou výzvu školních psychologů vycházející z evropské politiky zdraví rozvíjet duševní zdraví, well-being, silné stránky a potenciál žáků a učitelů. Mareš (2016) zase připomíná povinnost školního psychologa podílet se na výzkumných aktivitách, přičemž se mimo jiné odkazuje na dokument Mezinárodní asociace školní psychologie (International School 
Psychology Association - ISPA, 2019), jejíž členem je také Česká republika a Slovenská republika.

Smékalová (2014) i Hanauerová (2017) upozorňují na riziko nepochopení role školního psychologa (např. požadavky na vykonávání činností, které nespadají do jeho kompetence ani standardních činností jako dozor na chodbách, suplování apod.). Nejisté prrijetí souvisí také s profesní identitou: školní psycholog musí mnohdy své postavení neustále vybojovávat a obhajovat (Štech \& Zapletalová, 2013).

Školní psychologové na rozdíl od psychologů z pedagogicko-psychologických poraden pracují prímo ve škole. Výhodou je možnost zaměřit se na pravidelnější a systematičtější spolupráci s žáky a jejich rodiči. Také mohou kontinuálně sledovat vývoj žáků od 6 do 15 let v jejich přirozeném prostředí (Hubertová, 2014). Školní psychologové mohou působit na problémy $\mathrm{v}$ jejich počátcích nebo jim dokonce vhodnou prevencí předcházet. Díky své přítomnosti na škole mohou rychle reagovat na obtíže žáků nebo učitelů. Mají relativně rychlou zpětnou vazbu na svou práci, nebot' jsou v kontaktu s žáky a vidí, jaké dělají pokroky. Při své práci se potkávají s žáky, kterým pomohli, ale také s žáky, u kterých spolupráce skončila neúspěchem.

Oproti psychologům v pedagogicko-psychologických poradnách nemají školní psychologové tak dobré podmínky pro diagnostikování a nedostává se jim intervize od kolegů na pracovišti (Braun a kol., 2014). Na osamělost a určitou izolaci od jiných kolegů psychologů, náročnou zejména pro začínající školní psychology, upozorňují Vozková a Vanek (2018). Osamělost a izolovanost školního psychologa je umocněna i tím, že by jako profesionál neměl navazovat důvěrnější vztahy s učiteli a vedením školy. Na jedné straně stojí pozitiva jako je smysluplnost práce, pohotovost, svoboda v uspořádání a plánování vlastní práce, na druhé straně jsou negativa, jako je náročné usměrňování představ a očekávání účastníků systému, tedy vedení školy, učitelů, rodičů a žáků, kteří obvykle očekávají okamžité řešení a pozitivní výsledky. Každodenní vymezování své role spojené s určitým odstupem od ostatních zaměstnanců školy, které musí přesvědčit o svém prŕnosu, je pro školní psychology psychicky náročné. Na to navazuje další složitý úkol - působit jako vyjednávač dobrých vztahů mezi aktéry školy (Štech \& Zapletalová, 2013).

Zahraniční výzkumy uvádějí jako zdroje nespokojenosti školních psychologů platové ohodnocení, nemožnost povýšení, zásady a pravidla školského systému (VanVoorhis \& Levinson, 2006; Worrell et al., 2006).

Podle zjištění Kavenské, Smékalové a Šmahaje (2013) pracovní spokojenost školních psychologů koreluje s přijetím ze strany vedení škol a pedagogů. Výzkum Palové a Šmahaje (2020) si kladl otázku, jak se školní psychologové cítí přijímáni na škole jednotlivými subjekty. Na škále 1-5, kdy 1 znamená nejlépe, zjistili průměrné hodnoty na úrovni vedení školy $(1,58)$, žáků $(1,56)$, metodiků prevence $(1,63)$, výchovných poradců $(1,53)$, rodičů $(1,85)$ a pedagogů $(1,92)$.

Štech a Zapletalová (2013) upozorňují na důležitost dobrých vztahů s vedením školy pro fungující působení školního psychologa. Přitom v běžném povědomí kultivace v tomto ohledu nepatří k hlavním dovednostem psychologa. Převažuje názor, že o vedení školy nejde, kvůli němu psycholog na škole není. Podceňování vztahů s ředitelem školy se tak často stává zdrojem potíží.

Podle Štecha a Zapletalové (2013) školní psychologové považují vztahy s učiteli za jeden z nejvíce zátěžových aspektů své práce. Pokud má školní psycholog dobré vztahy s učiteli, 
může pozitivně ovlivňovat jejich práci, a tím i klima celé školy. Vztah školního psychologa s učiteli je v několika aspektech rozporuplný. Na jedné straně by měl být školní psycholog neutrální a udržovat si od učitelů určitý odstup, na druhé straně stojí úkol být pro učitele důvěryhodný a nevyvolávat $\mathrm{u}$ nich pocit ohrožení. Měl by udržovat dobré vztahy s učiteli, spolupracovat s nimi, ale musí dodržovat zásady etického kodexu školních psychologů1. Velmi problematická je práce s učitelem, který svým chováním přispívá k problémům žáka či negativně ovlivňuje klima třídy a školy (Braun a kol. 2014). Podobné situace mohou vést k tzv. morálnímu distresu, který Jameton (1993, s. 542) definoval následovně: „Jedinec zažívá morální distres, když dospěje k morálnímu závěru o případu, který sám řeší, ale instituce nebo spolupracovníci mu zkomplikují nebo prímo znemožní jednat v duchu tohoto rozhodnutí.“ Problematikou morálního distresu u školních psychologů se v České republice zabývá především Mareš (2017), na Slovensku Bakaričová a Lajčiaková (2019).

Spolupráce s rodiči bývá považována za náročnou část práce školního psychologa. Často je pro zlepšení potíží žáka nutné pracovat s celým rodinným systémem delší dobu. Rodiče problémových dětí mívají malou důvěru v instituce jako je škola a mnohdy mají nízkou ochotu pomáhat v řešení problému (Štech \& Zapletalová, 2014).

Výčet kladů a záporů profese zmiňovaný $v$ této podkapitole vychází především ze zkušenosti autorů článků a monografií. Rozhodli jsme se jejich odborné názory doplnit výzkumným šetřením, v němž nás zajímalo, s jakou četností budou jednotlivé výhody a úskalí jmenovat školní psychologové a zda je všechny zmíní.

\section{Cíl př́spěvku}

Hlavním cílem příspěvku je prozkoumat klady a zápory profese školní psychologie očima školních psychologů. Dílčím cílem je zjistit úroveň spokojenosti s povoláním školního psychologa a souvislosti s věkem, délkou praxe a výší úvazku.

Z formulace cílů prríspěvku vyplynuly následující výzkumné otázky:

- Jaké klady vnímají školní psychologové na své práci?

- Jaké zápory vnímají školní psychologové na své práci?

- Jaká je úroveň spokojenosti školních psychologů s výkonem povolání?

- Existuje souvislost mezi úrovní spokojenosti s povoláním školních psychologů a věkem, délkou praxe a výší úvazku školních psychologů?

\section{Metodologie výzkumného šetření}

Jedná se o empirickou studii se smíšeným výzkumným designem, přičemž data byla zajištěna jednorázovým dotazníkovým šetřením.

\footnotetext{
${ }^{1}$ Oakland, T., Goldmanová, S., \& Bishoff, H. (1997). Etické normy práce školního psychologa. http://www.nuv.cz/file/3654?lang=1 [přeloženo z angličtiny, viz Oakland, T., Goldman, S., \& Bishoff, H. (1997). Code of Ethics of the International School Psychology Association. School Psychology International, 18(4), 291-298. https://doi.org/10.1177/0143034397184001]
} 
Výzkumný soubor byl tvořen 61 osobami ve věku od 24 do 68 let $(M=36,18 ; S D=9,52)$, které v současnosti pracují na pozici školního psychologa. V souboru bylo zastoupeno 48 školních psychologů působících na základních školách $(78,7 \%), 11$ pracující na středních školách (18,0 \%) a 2 pracující ve speciálních školách (3,3\%), přičemž 30 (tj. 49,2 \%) školních psychologů pracuje na poloviční nebo menší úvazek. Z hlediska pohlaví bylo v souboru 59 žen $(96,7 \%)$ a 2 muži $(3,3$ \%). Z hlediska krajů bylo v různé míře zastoupeno všech 14 krajů. Rozložení výzkumného souboru podle území je následující: Jihomoravský kraj $n=10$, Praha $\mathrm{n}=9$, Pardubický $\mathrm{n}=8$, Ústecký $\mathrm{n}=5$, Zlínský $\mathrm{n}=5$, Středočeský $\mathrm{n}=4$, Moravskoslezský $\mathrm{n}=4$, Olomoucký $\mathrm{n}=4$, Jihočeský $\mathrm{n}=4$, Vysočina $\mathrm{n}=2$, Karlovarský $\mathrm{n}=2$, Liberecký $\mathrm{n}=2$, Východočeský $\mathrm{n}=1$, Královehradecký $\mathrm{n}=1$.

Jako výzkumný nástroj byl zvolen elektronický dotazník vlastní konstrukce, který byl opakovaně distribuován během záŕí až listopadu 2019 prostřednictvím e-mailových adres a facebookové skupiny pro školní psychology. Dotazník obsahoval 15 otázek (8 otázek kvantitativních, 7 otázek kvalitativních). Výsledky uvedené v tomto př́spěvku se týkají 7 otázek kvantitativních (zjišt’ujících pohlaví, věk, délku praxe, kraj, typ školy, úvazek, spokojenost) a 2 otázek kvalitativních (dotazujících se na klady a zápory profese).

Data byla zpracována v programu IBM SPSS Statistics 22.0. Data byla analyzována pomocí deskriptivních parametrických statistik. Ke zjištění vztahu mezi úrovní pracovní spokojenosti a věkem, délkou praxe a výší úvazku školních psychologů byla použita korelační analýza (Pearsonův korelační koeficient). Odpovědi vztahující se ke kladům a záporům profese školních psychologů byly zpracovány kvalitativně pomocí metody konstantní komparace. Následně byla použita frekvenční analýza k uvedení četnosti odpovědí respondentů k jednotlivým vytvořeným kategoriím.

\section{Výsledky výzkumu}

Stupeň spokojenosti s povoláním měli školní psychologové možnost vyjádřit na škále od 1 do 10 , přičemž $1=$ nejméně spokojeni a $10=$ hodně spokojeni. Nejčastěji volená hodnota byla 8 $(44,3 \%)$, průměrná hodnota spokojenosti byla 7,66 $(\mathrm{SD}=1,38)$. Podrobnější výsledky ukazuje obrázek 1.

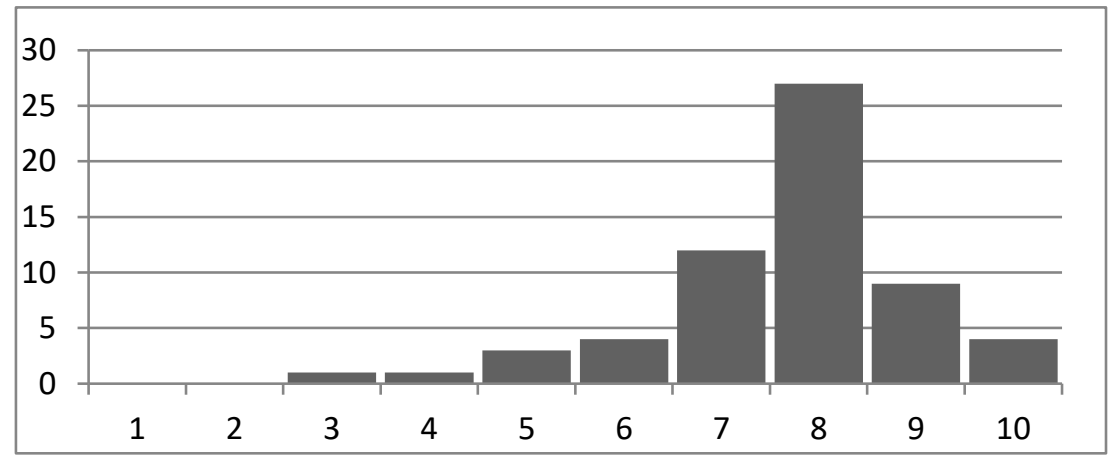

Obrázek 1. Pracovní spokojenost školních psychologů

Dále bylo zjišt’ováno, jak souvisí spokojenost s povoláním školního psychologa s věkem, délkou praxe a výší úvazku školních psychologů. K výpočtu byl zvolen Pearsonův korelační koeficient. Pracovní spokojenost statisticky významně pozitivně koreluje s délkou praxe 
$(\mathrm{r}=0,273 ; \mathrm{p}<0,05)$ a výší úvazku $(\mathrm{r}=0,276 ; \mathrm{p}<0,05)$. Naopak mezi pracovní spokojeností a věkem školních psychologů nebyl nalezen žádný statisticky významný korelační vztah $(\mathrm{r}=0,148 ; \mathrm{p}>0,05)$.

Mnozí respondenti odpovídali na otevřené otázky obsáhle, např́íklad uváděli několik kladů nebo záporů své profese. Takové odpovědi jsme rozdělili na několik významových segmentů a řadili k několika kategoriím. Součet odpovědí v jednotlivých kategoriích proto většinou neodpovídá celkovému počtu respondentů.

V následujících odstavcích představujeme výsledky výzkumu. První část výsledků se věnuje kladům práce školních psychologů a druhá část se týká záporů.

\section{Analýza kladi̊ práce školního psychologa}

Ke zpracování odpovědí školních psychologů vztahujících se k výzkumné otázce ohledně vnímaných kladů byla použita metoda konstantní komparace. Vzniklo osm kategorií, přičemž někteří respondenti ve svých odpovědích zmiňovali víc jak jednu kategorii. Výsledky jsou ukázány $\mathrm{v}$ tabulce 1 .

Tabulka 1

Četnost odpovědi k vnímaným kladi̊m $(n=61)$

\begin{tabular}{lll}
\hline Kategorie & Zmínilo se (n) & $\%$ \\
\hline Kontakt s klientem & 36 & 59 \\
Volnost & 21 & 34 \\
Rozmanitost & 21 & 34 \\
Pracovní podmínky & 13 & 21 \\
Smysl a naplnění & 12 & 20 \\
Profesní rozvoj & 6 & 10 \\
Méně administrativy & 4 & 7 \\
Prevence & 3 & 5 \\
\hline
\end{tabular}

\section{Kontakt s klientem}

Nejpočetněji (36 osob, tj. 59 \%) bylo zmiňované jako pozitivum kontakt s klientem. Šestnáct respondentů kladně hodnotí dostupnost a možnost být v přímém kontaktu s klienty: ,, snadná $a$ rychlá dostupnost poradenské pomoci pro děti/ rodičel pedagogy“, „služba je pro rodiče zdarma a frekvence individuálních setkání s dítětem může být nastavena dle potřeby (klidně $i$ několikrát za týden) ". Možnost okamžitě reagovat v př́padě problému uvedlo šest osob: „,možnost působit okamžitě, když je problém, děti není třeba odesílat někam mimo a čekat“. Dalších šest respondentů ve svých výpovědích poukázalo na výhodu být v přirozeném prostředí školy: ,, možnost práce s dětmi v přirozeném prostředi, propojit zkušenosti ziskané v přirozeném 
prostředís individuální praci“", „, možnost zmapovat vzniklý problém z více stran a možnost díky tomu najít jeho účinnějši ř rešeni". Tři respondenti kladně hodnotí, že mohou pracovat se všemi žáky: ,, setkávání se se širokou normou (nejen s výsekem společnosti) “, „práce i se "zdravou” populaci“". Dvanáct respondentů oceňuje, že mohou pomáhat a pracovat s lidmi: ,, "ochrana a útočiště" pro děti, rodiče $i$ pedagogy", z toho jedna respondentka se rozepsala o pomoci učitelům: „Vnímám, jak má doporučení berou jinak, než doporučení z ppp (myšleny pedagogicko-psychologické poradny)... Z poraden se většinou dozvídají - po dvou měsících čekání - "rady", které dávno dělají... Nap̌r., že maji umožňovat dítěti krátkou přestávku mezi činnostmi, maji hledat drobné úspěchy u dítěte, presadit si ho bliž nebo v učivu navazovat na již zvládnuté učivo... Tyto rady učitele právoplatně uráži a vzniká tak zbytečný tlak a nedůvěra $v$ práci odborníků v ppp... Ale opodstatněná... Učitelé musí s dítětem pracovat denně a $v$ kolektivu. Psycholog v poradně vidi ditě dvě hodiny o samotě... A pak podává tento typ rad... Nedivím se učitelưm, že pak $k$ vyšetření nemaji důvěru, mnohdy jsou totiž zprávy z poraden $v$ doporučeních $i$ viditelně zkopirované odjinud! Učiteli mnohdy stačí, že si může "ulevit", jak obtížnou třídu má, že už vyzkoušel kdeco a neví si rady, aby měl chut' jít dál. Upozornění z poradny, že dělá stále málo ho demotivuji. " Jedna respondentka poukázala na výhodu sledovat problém $\mathrm{v}$ čase.

\section{Volnost}

Volnost kladně kvituje 21 respondentů (tj. $34 \%$ ). Z toho 7 respondentů zmiňuje volnost časovou - svoboda, kdy co dělám: „svoboda plánováni“", „časová flexibilita - mohu si práci rozvrhnout, jak potřebuji“. Pět respondentů popisuje volnost ve způsobu pojetí práce svoboda, jak co dělám: ,volné pole pưsobnosti, aktivity jsou čistě v mé režii, volím takový způsob práce, ve kterém se cítím nejlépe “. Čtyři respondenti oceňují flexibilní pracovní dobu. A zbylých pět respondentů volnost nespecifikovalo (,,volnost v práci“, ,, volná ruka“).

\section{Rozmanitost}

Rozmanitost své profese kladně hodnotí 21 respondentů (tj. 34 \%). Ve svých odpovědích uvádí rozmanitost cílových skupin, způsobů práce i témat, které řeší: „tvořivost, práce s jednotlivci i skupinami, s dospělými $i$ dětmi - vice cílových skupin pohromadě“, ,zkoušet různé metody“, „,možnost setkat se s různými tématy“.

\section{Pracovní podmínky}

Pracovní podmínky povolání školního psychologa zmiňovalo 13 respondentů, tj. $21 \%$ ze vzorku. Přičemž 10 respondentů oceňuje delší dovolenou (,, volné léto "), 3 respondenti možnost pracovat ve škole (,„škola je zajímavý organismus“, „,zaštítění školou“), 1 respondent platové podmínky (,stabilní plat oproti nap̌r. Psychoterapeutovi na OSVČ“) a 1 respondent oceňuje společenské postavení.

\section{Smysl a naplnění}

Jako smysluplnou a naplňující popisuje svou práci 12 respondentů (tj. $20 \%$ \%). Přičemž 6 respondentů vnímá svou práci jako smysluplnou: „věnovat se činnostem, které mi dávají smysl“. Tři respondenti vidí smysl v př́ležitosti zlepšit systém školství: „,možnost měnit školstvi “. Čtyři respondenti vnímají svou práci jako naplňující: ,obrovský pocit uspokojeni'“. 


\section{Profesní rozvoj}

Šest osob (tj. $10 \%$ ) zmiňuje jako pozitivum možnost profesního rozvoje a vzdělání. Př́ikladem jsou následující výpovědi: „,neustálé výzvy, neustálá nutnost vzdělávat se a profesně růst“, „,možnost rozvíjet se v individuálním poradenství i v práci s kolektivy“.

\section{Méně administrativy}

Několik respondentů $(4$, tj. 7 \%) uvádělo jako jeden z kladných aspektů své práce méně administrativy.

\section{Prevence}

O pozitivu jako je možnost působit preventivně vypovídali 3 respondenti (tj. $5 \%$ ): „možnost preventivně udržovat pozitivní klima ve třídách $i$ ve škole“.

\section{Analýza záporů práce školního psychologa}

Zpracováním odpovědí školních psychologů vztahujících se k výzkumné otázce ohledně vnímaných záporů vzniklo sedm kategorií, jak ukazuje tabulka č. 2. Někteří respondenti ve svých odpovědích zmiňovali více než jednu kategorii.

Tabulka 2

Četnost odpovédí $k$ vnímaným záporům $(n=61)$

\begin{tabular}{lll}
\hline Kategorie & Zmínilo se (n) & $\%$ \\
\hline Vztahy & 24 & 39 \\
Nejasná role & 21 & 34 \\
Osamocenost & 19 & 31 \\
Náročná práce & 17 & 28 \\
Nedostatečná supervize a systém vzdělávání & 9 & 15 \\
Finance & 8 & 13 \\
Nedostatečné vybavení & 3 & 5 \\
\hline
\end{tabular}

\section{Vztahy}

Vztahy jako jedno z negativ práce školního psychologa jmenuje 24 respondentů (tj. $39 \%$ ). $\mathrm{Z}$ toho 16 respondentů popisuje náročné vztahy s pedagogy - jejich nedůvěru, neochotu spolupracovat, neprofesionalitu: „rezistence některých pedagogů vůči změnám v prístupu kdětem“, „nepřijetí ze strany mnoha učitelù, neochota spolupráce mnoha učiteliu“, „,nepochopeni práce a úlohy psychologa staršimi pedagogy až odpor vůči jeho práci, dehonestace jeho práce pred dětmi, rodiči atd. “. Další tři respondenti zmiňují svou pozici mezi 
aktéry školy: „, tlaky z více stran - vedení x sborovna $x$ rodiče $x$ děti“, ,, spletitá sit' vztahů, $v$ nichž školní psycholog musí někdy působit jako určitý mediátor". Pouze tři respondenti zmiňují jako negativum vedení školy, jeden respondent děti a dva respondenti rodiče (,očekávání rodičủ - kouzelnou hůlku ani zázračnou pilulkou prostě NEMÁM :D, pocit zmaru, když dávám dohromady psychiku ditěte a vím že za dva týdny je tu zas protože jeho rodinná situace"). Jeden respondent popisuje negativní aspekty vyplývající z blízkosti klientů: „občasná potiž se zasazením př́mo do školy... potřeba lavírovat na hraně terapie a výchovy... “

\section{Nejasná role}

Někteří respondenti $(21$, tj. 34 \%) uvádějí jako nevýhodu nejasnou roli školního psychologa. Nedostatečné právní ukotvení zmiňují 4 respondenti: ,velká zodpovědnost bez jasných legislativních predpisů“. Dalším 17 respondentům vadí, že ostatní nebo i oni sami přesně nevědí, co by měl školní psycholog dělat, a také předsudky vůči profesi nebo nereálná očekávání: ,, neukotvenost pozice psychologa, kolegové a někdy i nadřizení nerozumí tomu, co psycholog dělá “, ,jde stále o pomèrně novou pozici (kdy je náplň hodně na řediteli dané školy) a ne všichni jsou na ni zvyklí a berou ji vážně. Je potřeba se prosazovat, být aktivní, ujasňovat si kompetence školního psychologa“, „,názor, že kdo chodi k psychologovi, musí být nějak divný, blázen apod.", „Očekávání, že dokážu pojmout celou škálu duševních obtiži a dokážu napravovat na počkání... “.

\section{Osamocenost}

Do kategorie Osamocenost bylo zařazeno 19 odpovědí (tj. $31 \%$ ). Z toho 11 respondentů popisovalo osamocenost od kolegů psychologů: ,,to, že je psycholog na pracovišti sám, nemá možnost rychlé konzultace s kolegy v konkrétní situaci“, „málo přimého kontaktu s kolegy psychology, mám většinou jen virtuální pres fb (myšleno Facebook) “. Dalších pět respondentů zmiňovalo osamocenost v rámci vztahů na škole: „psycholog do kolektivu zaměstnanců školy "moc nezapadá" - a pokud ano, pak se opět těžko dodržuje neutralita a profesionální hranice“. Tři respondenti napsali osamělost, ale ze stručného popisu nebylo zřejmé, o jaký typ osamělosti se jedná.

\section{Náročná práce}

Jako náročnou svou práci hodnotí 17 respondentů (tj. $28 \%$ ). Sedm respondentů poukazuje na př́liš mnoho práce a málo času: „,na jednoho psychologa připadá ohromné množství dětí časové možnosti pro preventivní působení jsou tedy značně umenšené “. Dva respondenti negativně hodnotí množství obtíží, se kterým se školní psycholog setkává: ,, musí re ̌̌it velmi široké spektrum obtǐží, někdy pracuje is dětmi které by měly jit k jinému odborníkovi, protože tam rodiče odmitaji jit". Šest respondentů kritizuje systém a spolupráci s dalšími odborníky: „,narážení na omezení systému, nefungujici instituce“, „občas přilišná svázanost školního systému, těžkopádnost a zdlouhavost v prijetí změn, dělání věcí jinak, nechut ke změnám “. Tři respondenti popisovali, jaké nároky na ně práce klade, případně jak se cítí: „, člověk by měl být obezřetný v tom co ř̉ká, velký tlak na osobnost - očekávání určitých charakteristik od psychologa“, „je náročné zůstávat neutrální a obhájit si, že stojím na straně dítěte (ne školy, ne rodičù, ne učitele...) “, „, občas pocit vnucování svých služeb “. Dva respondenti napsali, že je jejich práce náročná, stresující, ale ze stručného popisu nebylo zřejmé, z jakého důvodu. 


\section{Nedostatečná supervize a systém vzdělávání}

O nedostatečné supervizi a systému vzdělávání vypovídalo 9 respondentů (tj. $15 \%$ ). Šest respondentů záporně hodnotí nedostatečnou nebo chybějící supervizi, dva respondenti zmiňují nedostatečný systemický způsob vzdělání, jeden respondent píše o nedostatečném metodickém vedení, jednomu respondentovi vadí metodika: „metodika, která je zbytečně komplexní a vytvořená jak se zdá teoretikama namisto odborniků z praxe" a jednomu respondentovi se nelíbí způsob vzdělávání psychologů na vysokých školách: „,chtělo by to důkladnější prípravu během VŠ studia, protože nyní ve školách pracuje hodně psychologů a př́prava je minimální, ve školách se hrotí hlavně klinika, většina předmětů se jí týká".

\section{Finance}

Finance záporně hodnotí 8 osob (tj. 13 \%). Čtyři respondenti nejsou spokojeni se svým platovým ohodnocením. U tří respondentů je zmínka o nejasnosti financování jejich pozice do budoucna: „chybí návaznost financování po skončení grantù“, ,nejistota našich pozic ve školství - poloviční úvazky, nejistota smlouvy na dobu neurčitou, financování" a jednomu respondentovi vadí pracovní poměr na dobu určitou.

\section{Nedostatečné vybavení}

Zmínka o nedostatečném vybavení se objevuje ve výpovědích 3 respondentů (tj. $5 \%$ ): „ne zcela vyhovujicí prostory kanceláře ".

\section{Shrnutí a diskuse výsledků}

Cílem příspěvku bylo analyzovat klady a zápory profese školní psychologie očima školních psychologů. Dále byl výzkum zaměřen na úroveň pracovní spokojenosti školních psychologů a na souvislosti mezi touto pracovní spokojeností a věkem, délkou praxe a výší úvazku školních psychologů.

Odpovědi školních psychologů v souvislosti s výzkumnou otázkou týkající se kladů profese byly pomocí metody konstantní komparace shrnuty do osmi kategorií. Jsou jimi výhoda prímé práce s klientem, volnost, rozmanitost, pracovní podmínky, smysl a naplnění, profesní rozvoj, méně administrativy a možnost prevence. Zmiňované výhody korespondují s výčtem výhod uvedených v českých monografiích věnovaných školní psychologii (Braun a kol., 2014; Štech \& Zapletalová, 2013). Podobají se důvodům zájmu o obor školní psychologie, které ve výzkumu zmiňovali slovenští studenti psychologie (Vašašová \& Tóth, 2015). Mezi nejčastější důvody uváděli práce s lidmi/pomoc lidem (42\%), práce ve školním prostředí (16 \%), obohacení o nové zkušenosti (11\%) a rozmanitost (11\%).

Na výzkumnou otázku dotazující se na zápory práce školního psychologa jsme pomocí metody konstantní komparace našli odpověd' ve formě sedmi kategorií. Za zápory profese byly označeny náročné vztahy, nejasná role, osamocenost, náročná práce, nedostatečná supervize a systém vzdělávání, finance. Ve výzkumu Vašašové a Tótha (2015) slovenští studenti psychologie jako nejčastější důvody nezájmu o povolání školního psychologa uváděli nezájem o práci se žáky/ práci ve školství (28 \%), nedocenění (21\%), nízké finanční ohodnocení (19\%), monotónnost práce, řešení jen školních problémů (19\%). V monografii Štecha a Zapletalové (2013) je nastíněn problém autonomie školního psychologa související s otázkou, do jaké míry a v čem může podléhat svému zaměstnavateli (vedení školy). Jako další úskalí jsou zmíněny 
vztahové situace jako jsou rodinné dysfunkce u žáků nebo nežádoucí zásahy učitelů. Jedná se o náročné situace, nebot' nemají jasnou strukturu, ani neindikují nástroje a metody, které použít, a mají těžko předvídatelné následky. Podle Smékalové (2014) chybí provázání práce školního psychologa s dalšími poradenskými službami a vize rozvoje tohoto povolání do budoucna. O problému autonomie, nejasnosti nástrojů či metod, které by školní psychologové měli použít, nebo chybějící vize rozvoje, se nikdo ze 61 respondentů explicitně nezmínil. Otázkou je, zda si tato úskalí uvědomují, a pokud ano, zda se s nimi potýkají.

Podle dokumentu Mezinárodní asociace školní psychologie (International School Psychology Association, 2019) je povinností školního psychologa podílet se na výzkumných aktivitách. Podle Mareše (2016) je nejméně výzkumných aktivit u školních psychologů pracujících v terénu (tj. na základních a středních školách). Dotazovali jsme se na klady a zápory práce, nikoliv na pracovní nápln̆, přesto ani u jedné odpovědi se nenašla zmínka o výzkumné činnosti, což podporuje Marešovo tvrzení. Zatímco práce s klientem, učitelem, rodičem, třídou a administrativní nároky zmíněny byly.

Výzkumná otázka se týkala i úrovně pracovní spokojenosti školních psychologů. Školní psychologové jsou spokojeni se svou prací, což dokládá průměrná hodnota spokojenosti 7,66 $(\mathrm{SD}=1,38)$ hodnocená na škále od 1 do 10 , přičemž $1=$ nejméně spokojeni a $10=$ hodně spokojeni. Toto zjištění odpovídá výzkumu Kavenské, Smékalové a Šmahaje (2013), v němž bylo pracovně spokojeno 52 školních psychologů a nespokojeni pouze 3. O vysoké úrovni spokojenosti školních psychologů referují i zahraniční výzkumy (VanVoorhis \& Levinson, 2006; Worrell et al., 2006).

Zajímavé zjištění přináší mezinárodní srovnávací výzkumy. V ekonomicky slabších a z pohledu zavedení školní psychologie „mladších“ zemí jsou nižší nároky na vzdělání a praxi školních psychologů, $v$ jejich pracovní náplni převažuje přímá práce $\mathrm{s}$ žákem a zejména administrativní činnosti jsou zastoupeny nevýznamně. Nepřímá činnost jako administrativa, vzdělávání učitelů, konzultace s učiteli, konzultace s rodiči, primární prevence převládá u vyspělejších států. Přitom s naplňováním svých ideálních představ v souvislosti s náplní práce jsou více spokojeni školní psychologové z ekonomicky slabších zemí než psychologové z vyspělých (Štech \& Zapletalová, 2013). Česká republika se řadí k zemím z pohledu zavedení školní psychologie „mladším“s převažující prrímou prací, tudíž by školní psychologové měli být pracovně spokojenější, což je v souladu s naším výzkumným zjištěním.

Odpověd' na výzkumnou otázku zabývající se souvislostí mezi pracovní spokojeností a věkem, délkou praxe a výší úvazku školních psychologů je, že pracovní spokojenost statisticky významně pozitivně koreluje $\mathrm{s}$ délkou praxe $(\mathrm{r}=0,27)$ a výší úvazku $(\mathrm{r}=0,28)$. Naopak mezi pracovní spokojeností a věkem školních psychologů nebyl nalezen žádný statisticky významný korelační vztah. Je pravděpodobné, že čím delší praxi má školní psycholog, tím je zorientovanější ve své roli, on i ostatní aktéři ve škole mají jasnější očekávání, zvyšuje se důvěra v jeho schopnosti v očích učitelů, žáků, rodičů, vedení školy, což vede $\mathrm{k}$ větší pracovní spokojenosti. Je možné, že čím má psycholog vyšší úvazek na škole, tím více se může věnovat prŕmé práci se žáky, působit preventivně, je lépe přijímán aktéry školy, což přispívá k jeho vyšší pracovní spokojenosti. Tyto domněnky doporučujeme ověřit dalšími výzkumy.

Pracovní spokojenost souvisí s dalšími proměnnými. Např́iklad výzkum Kavenské, Smékalové a Šmahaje (2013) zjistil pozitivní korelační vztahy mezi pracovní spokojeností školních psychologů a tím, jak je přijímají učitelé $(r=0,26)$, vedení školy $(r=0,51)$ a žáci $(\mathrm{r}=0,23)$. 
K limitům naší studie patří nedostatečná reprezentativnost výzkumného souboru. Nepodařilo se nám zjistit celkový počet školních psychologů v České republice spolu s jejich kontaktními údaji, na které by bylo možné zaslat dotazníkové šetření. Dalším limitem je nízký počet respondentů, přičemž ve výzkumném souboru jsou pouze dva muži. Za další omezení výzkumu by mohl být označen způsob sběru dat a vytvořené kategorie. Klady a zápory práce školního psychologa byly zjišt’ovány pouze dotazníkovým šetřením, na jehož základě byly vytvořeny typologie kladů a záporů. Odpovědi v dotaznících jsou obvykle stručné, a ne vždy je možné plně pochopit, co tím dotyčný myslel, a jak spolu jednotlivé aspekty souvisí.

\section{Závěr}

Klady a zápory profese školního psychologa jsou popisovány v českých článcích i knihách (Braun a kol, 2014; Smékalová, 2014; Štech \& Zapletalová, 2013; Vozková \& Vanek, 2018; Zapletalová, 2001). Autoři se mnohdy opírají o svou vlastní praxi školního psychologa. Jak se na klady a zápory své práce dívají jiní školní psychologové? V našem výzkumu patří mezi nejčastěji zmiňované klady možnost př́mé práce s klientem, volnost a rozmanitost, naopak nejčastěji zmiňovanými zápory jsou náročné vztahy, nejasná role a osamocenost. V souvislosti s osamoceností a specifickým postavením školního psychologa v rámci školy se vynořuje jako možné řešení koncept dvou psychologů na škole (např́iklad dvou s polovičním úvazkem namísto jednoho školního psychologa s celým úvazkem). O výhodách a nevýhodách pojednává článek autorů Vozková a Vanek (2018).

Povolání školního psychologa je označované za náročné (Štech \& Zapletalová, 2013). Lazarová (2008, s. 486) napsala: „Školní psychologie rozhodně není jednoduchý obor a zdá se, že mezi psychology zatím nepatří mezi nejoblíbenější. Každý psycholog si musí své postavení ve škole sám vybojovat a $\mathrm{v}$ tomhle ohledu mu nemůže pomoci žádná legislativní podpora“. V tomto kontextu je potěšující, že v našem výzkumném souboru vykazují školní psychologové vysokou průměrnou pracovní spokojenost. Podle našich zjištění tato spokojenost souvisí s délkou praxe i výší úvazku školních psychologů.

\section{Literatura}

Bakaričová, I., \& Lajčiaková, P. (2019). Školský psychológ a morálny distres. Školský psychológ/Školní psycholog, 20(1), 10-16.

Bartoňová, M., Pipeková, J., Viktorin, J., \& Vítková, M. (2019). Rozšíření školního poradenského pracoviště o pozici školního speciálního pedagoga a školního psychologa. Online Journal of Primary and Preschool Education, 3(1), 1-8. https://doi.org/10.21062/ujep/326.2019/a/2533-7106/ojppe/2019/3/1

Borečková, K. (2018). EU šablony II klepou na dveře. https://www.veskole.cz/clanky/eusablony-ii-klepou-na-dvere

Braun, R., Marková, D., \& Nováčková, J. (2014). Praktikum školní psychologie. Praha: Portál.

Gajdošová, E. (2017). Nové výzvy a nové úlohy školských psychológov v kontexte európskej a slovenskej politiky zdravia. Školský psychológ/ Školní psycholog, 18(1), 8-13.

Gajdošová, E., \& Valihorová, M. (2019). Profesijné role a profesijné kompetencie školských psychológov v súčasněj škole. Školský psychológ/Školní psycholog, 20(2), 22-33. 
Hanauerová, Z. (2017). Problematické situace, které přináší pozice školního psychologa. Bakalářská práce. Praha: Univerzita Karlova. https://dspace.cuni.cz/bitstream/handle/20.500.11956/92783/BPTX_2016_2_11270_0_34 9492_0_191696.pdf? sequence $=1$

Hubertová, L. (2014). Školní psycholog: Jaký má význam pro školu? Kazuistiky z praxe. Psychologie pro praxi, 49(1-2), 123-129.

International School Psychology Association, (2019). A Definition of School Psychology. Dostupné z: https://www.ispaweb.org/a-definition-of-school-psychology/

Jameton, A. (1993). Dilemmas of moral distress: Moral responsibility and nursing practice. AWHONN's Clinical Issues in Perinatal and Women's Health Nursing, 4(4), 542-551.

Kavenská, V., Smékalová, E., \& Šmahaj, J. (2013). School psychology in the Czech Republic: Development, status and practice. School Psychology International, 34(5), 556565. https://doi.org/10.1177/0143034312469759

Knotová, D. a kol. (2014). Školní poradenství. Praha: Grada.

Lazarová, B. (2008). Školní psychologie v České republice po roce 1989. Československá psychologie, 52(5), 480-492.

Mareš, J. (2016). Školní psycholog jako výzkumník: zamyšlení nad možnostmi. Pedagogická orientace, 26(1), 5-23. https://doi.org/10.5817/PedOr2016-1-5

Mareš, J. (2017). Morální distres školních psychologů. Pedagogická orientace, 27(2), 308343. https://doi.org/10.5817/pedor2017-2-308

Palová, K, \& Šmahaj, J. (2020). Práce školního psychologa se třídou na základních školách. E-psychologie, 14(1), 1-18. https://doi.org/10.29364/epsy.363

Smékalová, E. (2014). Školní psycholog - ohrožený druh? Současná situace ve školním poradenství v České republice. E-psychologie, 8(4), 23-29. Dostupné z https://epsycholog.eu/pdf/smekalova.pdf

Štech, S., \& Zapletalová, J. (2014). Úvod do školní psychologie. Praha: Portál.

VanVoorhis, R. W., \& Levinson, E. M. (2006). Job satisfaction among school psychologists: A meta-analysis. School Psychology Quarterly, 21(1), 77-90. https://doi.org/10.1521/scpq.2006.21.1.77

Vašašová, R., \& Tóth, R. (2015). Motivácia a postoje študentov psychológie k práci školského psychológa. Školský psychológ/Školni psycholog, 16(1), 46-54.

Vozková, A., \& Vanek, M. (2018). Dva školní psychologové na jedné škole aneb ,je 0,5 + 0,5 větší, menší nebo rovno 1?“. Školský psychológ/Školní psycholog, 19(1), 24-32.

Worrell, T. G., Skaggs, G. E., \& Brown, M. B. (2006). School psychologists' job satisfaction: A 22-year perspective in the USA. School Psychology International, 27(2), 131-145. https://doi.org/10.1177/0143034306064540

Zapletalová, J. (2001): Co dělá školní psycholog? Kritická místa profese. Pedagogika, 51(5), 37-46.

\section{Legislativa}

Vyhláška č. 72/2005 Sb., o poskytování poradenských služeb a školských poradenských zařízeních, ve znění pozdějších předpisů. https://www.zakonyprolidi.cz/cs/2005-72

Vyhláška č. 116/2011 Sb., kterou se mění vyhláška č. 72/2015 Sb., o poskytování poradenských služeb a školských poradenských zařízeních. https://www.zakonyprolidi.cz/cs/2011-116

Zákon č. 82/2015 Sb., kterým se mění zákon č. 561/2004 Sb., o předškolním, základním, středním, vyšším odborném a jiném vzdělávání (školský zákon), ve znění pozdějších předpisů 


\section{Údaje o autorce}

Ing. et Ing. Mgr. Marie Herynková, Ph.D. pracuje na Pedagogické fakultě Univerzity Hradec Králové a také působí jako školní psycholožka na základní škole.

\section{Kontaktní údaje}

adresa: Pedagogická fakulta Univerzity Hradec Králové, Rokitanského 62, 50003 Hradec Králové III

e-mail: marie.herynkova@uhk.cz

Herynková, M. (2020). Spokojenost školních psychologů a pohled na klady a zápory jejich práce. E-psychologie, 14(3), 17-30. https://doi.org/10.29364/epsy.376 